\title{
Effect of Tide on Sewage Disposal by Bio-film Process Dosing with Enzyme
}

\author{
Gaimei Guo
}

College of Environmental Science and Engineering, Taiyuan University of Technology, Taiyuan 030600, China

gmguo@126.com

\author{
Keywords: Tide; TP; $\mathrm{NH}_{3}-\mathrm{N}$; COD; sewage
}

\begin{abstract}
The paper studied the effect of tide on the removal rate of COD, $\mathrm{NH}_{3}-\mathrm{N}$ and TP in the dosing pool in order to provide data to simulate disorderly discharged sewage in tidal rivers. Due to the dilute effect of rivers, the removal rate of $\mathrm{COD}, \mathrm{NH}_{3}-\mathrm{N}$ and $\mathrm{TP}$ at the tidal state was higher than that at no tidal state. At the tidal state, the average removal rate of $\mathrm{COD}, \mathrm{NH}_{3}-\mathrm{N}$ and $\mathrm{TP}$ was $60.8 \%$, $55.7 \%, 55.6 \%$. At no tidal state, the average removal rate of $\mathrm{COD}, \mathrm{NH}_{3}-\mathrm{N}$ and $\mathrm{TP}$ was $57.5 \%$, $47.5 \%, 8.6 \%$. At the tidal state, the upper bio-film was exposed to air and the activity of microorganism decreased, and the activity of microorganism was high at middle-level bio-film. Therefore, the utilization of bio-film at the tidal state was lower than that at no tidal state. However, due to the tidal action, rivers entered into the dosing pool and the dilute effect of rivers on the pollutants was obvious.
\end{abstract}

\section{Introduction}

Rivers had the important effect on the social form and economic development for towns. However, with the rapid development of industrialization and urbanization, as the survival of towns, rivers became sewage pipes of towns and had been seriously polluted, which threatened the health of human beings and the ecological environment. The efficient and economic governance of rivers had the positive significance for river restoration and ecological environmental protection. In china, the main reason of the river pollution was that domestic sewage and part of industrial wastewater along rivers and other runoffs which were seriously polluted were discharged into rivers by the ways of disorder, which caused the constant deterioration of rivers [1-3].

The paper studied the effect of tide on the removal rate of $\mathrm{COD}, \mathrm{NH}_{3}-\mathrm{N}$ and $\mathrm{TP}$ in the dosing pool in order to provide data to simulate disorderly discharged sewage in tidal rivers. At the tidal state, water flow pattern was the fluctuation turn flow, the level hydraulic retention time (HRT) was $16 \mathrm{~h}$, the range of temperature was $17 \sim 22^{\circ} \mathrm{C}$ and the average temperature was $20^{\circ} \mathrm{C}$. At no tidal state, water flow pattern was the fluctuation turn flow, HRT was16h, the range of temperature was $15 \sim 23^{\circ} \mathrm{C}$ and the average temperature was $20^{\circ} \mathrm{C}$.

\section{Test Device and Methods}

The research used continuous bio-film test device. The continuous bio-film reactors included the same three organic glass reactors. The every reactor volume was $1 \mathrm{~m}^{3}$ and the packing was combined fiber. The main reactors included two dosing pools and one contrast pool in order to compare the effect of multiple enzymes stimulant on treatment of sewage by bio-film process. Due to the concentration of dissolved oxygen (DO) was too low, in order to simulate the river, the test was carried out by aeration and the concentration of dissolved oxygen maintained about $2.5 \mathrm{mg} / \mathrm{L}$. The same three reactors ran at the same time. The all conditions during the tests for the three reactors were the same.

The influent was the wastewater from the sewage treatment plant of East China University of Science and Technology. The water quality for the experiments was shown in table 1. 
Table 1 The water quality for the experiments

\begin{tabular}{cccccc}
\hline water & $\mathrm{DO}(\mathrm{mg} / \mathrm{L})$ & $\mathrm{COD}(\mathrm{mg} / \mathrm{L})$ & $\mathrm{NH}_{3}-\mathrm{N}(\mathrm{mg} / \mathrm{L})$ & $\mathrm{TP}(\mathrm{mg} / \mathrm{L})$ & $\mathrm{pH}$ \\
\hline the sewage & $0 \sim 2$ & $244 \sim 370$ & $45 \sim 52$ & $2.6 \sim 4.2$ & $5 \sim 7.5$ \\
the river & $3 \sim 4$ & $50 \sim 55$ & $1 \sim 2$ & $0.1 \sim 0.5$ & $6.8 \sim 7.2$ \\
\hline
\end{tabular}

During the tide period, water flow was adjusted based on the highest level hdraulic retention time. The parameters for tide simulation were shown in table 2.

Table 2 The parameters for tide simulation

\begin{tabular}{cccc}
\hline $\begin{array}{c}\text { HRT } \\
(\mathrm{h})\end{array}$ & $\begin{array}{c}\text { tidal water flow } \\
\left(\mathrm{L}^{*} \mathrm{~h}^{-1}\right)\end{array}$ & $\begin{array}{c}\text { ebb tide time } \\
(\mathrm{h})\end{array}$ & $\begin{array}{c}\text { rising tide time } \\
(\mathrm{h})\end{array}$ \\
\hline 8 & 25 & 5 & 5 \\
16 & 27.5 & 5 & 5 \\
\hline
\end{tabular}

\section{Results and Discussion}

The paper studied the effect of tide on the removal rate of COD, $\mathrm{NH}_{3}-\mathrm{N}$ and TP in the dosing pool in order to provide data to simulate disorderly discharged sewage in tidal rivers. The water level of the dosing pool constantly changed with the change of ebb tide time. In the process of rising tide and ebb tide, the change rules of the water level in the dosing pool were shown in Fig.1 and Fig.2. In Fig.1, during ebb tide, the trend of the decrease of the water level in the dosing pool was slow after the first fast, and the trend was the same during rising tide (in Fig.2). Due to the change of the water level, the water pressure for inlet and outlet pressure was different $[4,5]$.

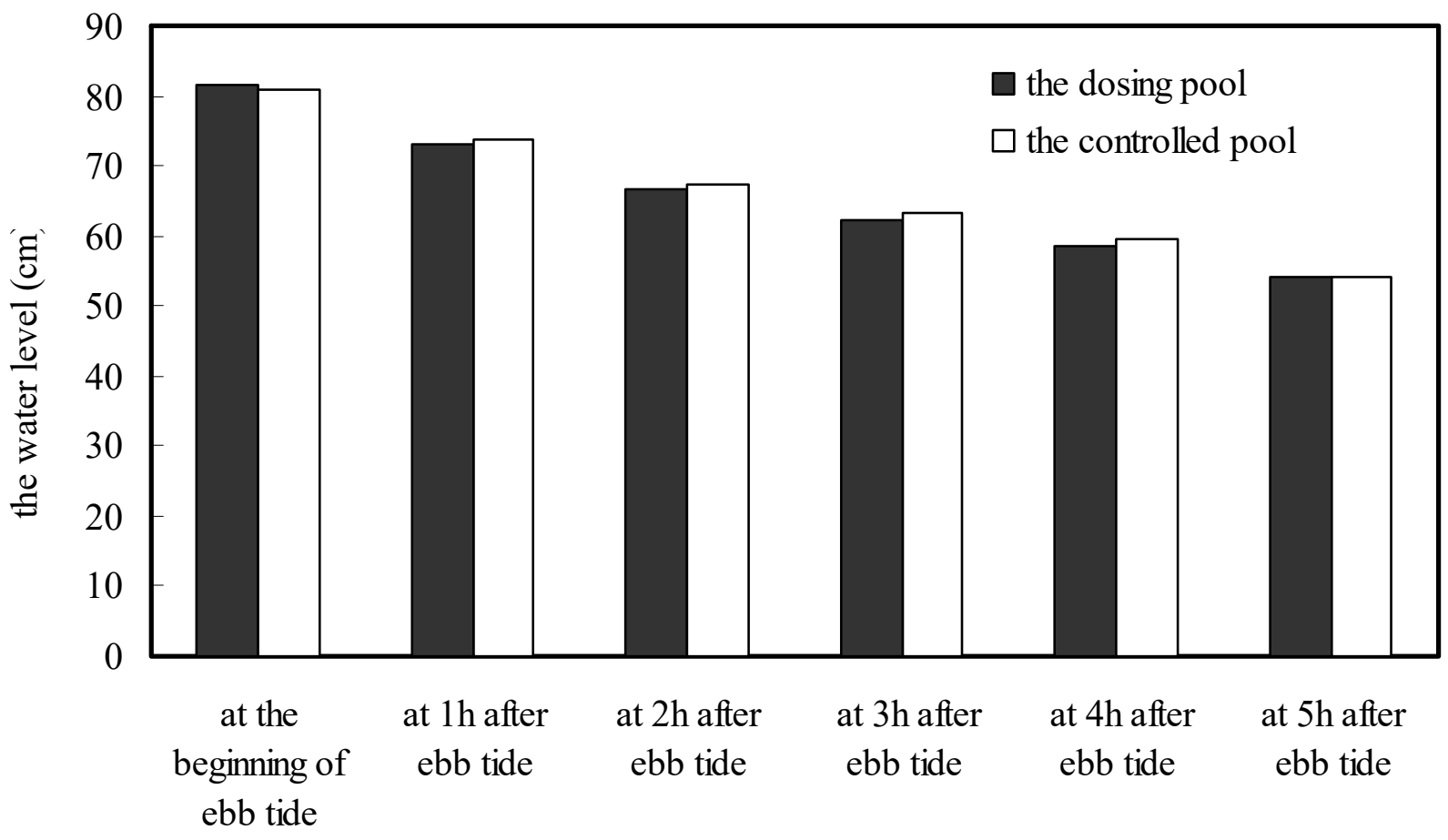

Fig.1 The variation of the water level at ebb tide 


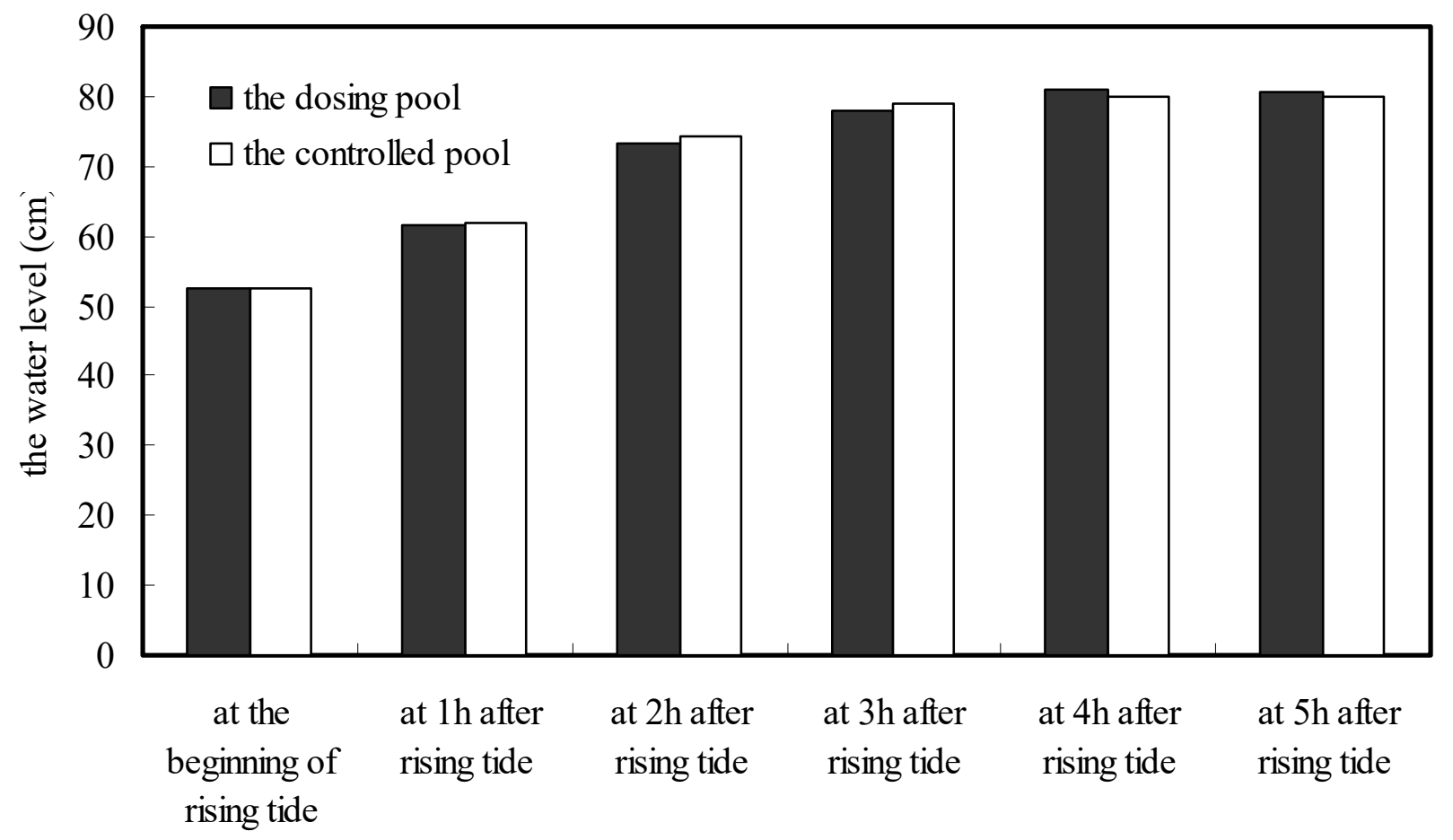

Fig. 2 The variation of the water level at rising tide

The removal rate of $\mathrm{COD}, \mathrm{NH}_{3}-\mathrm{N}$ and $\mathrm{TP}$ in the dosing pool at the tidal state and no tidal state was shown in Fig.3. At the tidal state, water flow pattern was the fluctuation turn flow, HRT was16h, the range of temperature was $17 \sim 22^{\circ} \mathrm{C}$ and the average temperature was $20^{\circ} \mathrm{C}$. At no tidal state, water flow pattern was the fluctuation turn flow, HRT was16h, the range of temperature was $15 \sim 23^{\circ} \mathrm{C}$ and the average temperature was $20^{\circ} \mathrm{C}$ [6].

The effect of tide on the removal rate of $\mathrm{COD}, \mathrm{NH}_{3}-\mathrm{N}$ and $\mathrm{TP}$ in the dosing pool could be obtained from Fig.3. Due to the dilute effect of rivers, the removal rate of COD, $\mathrm{NH}_{3}-\mathrm{N}$ and TP at the tidal state was higher than that at no tidal state. At the tidal state, the average removal rate of $\mathrm{COD}, \mathrm{NH}_{3}-\mathrm{N}$ and $\mathrm{TP}$ was $60.8 \%, 55.7 \%, 55.6 \%$. At no tidal state, the average removal rate of $\mathrm{COD}, \mathrm{NH}_{3}-\mathrm{N}$ and TP was $57.5 \%, 47.5 \%, 8.6 \%$. Because the concentration of TP in rivers was too low, the dilute effect of river was great. At the tidal state, the upper bio-film was exposed to air and the activity of microorganism decreased, and the activity of microorganism was high at middle-level bio-film [7]. Therefore, the utilization of bio-film at the tidal state was lower than that at no tidal state. However, due to the tidal action, rivers entered into the dosing pool and the dilute effect of rivers on the pollutants was obvious [8]. Therefore, the removal efficiencies of COD, $\mathrm{NH}_{3}-\mathrm{N}$ and $\mathrm{TP}$ at the tidal state were higher than those at no tidal state. 


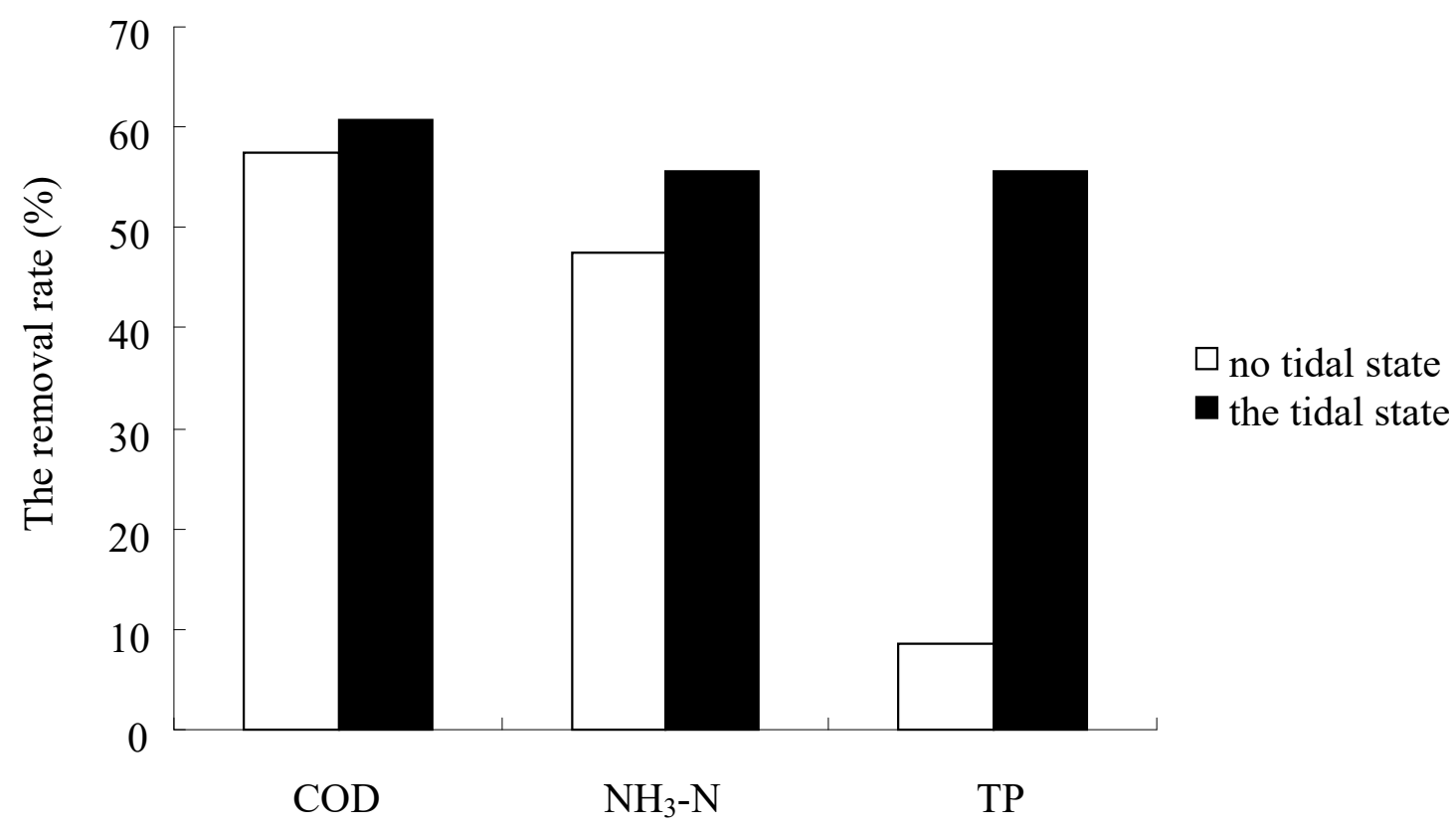

Fig.3 Comparison of COD, $\mathrm{NH}_{3}-\mathrm{N}$ and TP removal rates

\section{Conclusions}

The paper studied the effect of tide on the removal rate of $\mathrm{COD}, \mathrm{NH}_{3}-\mathrm{N}$ and $\mathrm{TP}$ in the dosing pool in order to provide data to simulate disorderly discharged sewage in tidal rivers. Due to the dilute effect of rivers, the removal rate of $\mathrm{COD}, \mathrm{NH}_{3}-\mathrm{N}$ and $\mathrm{TP}$ at the tidal state was higher than that at no tidal state. At the tidal state, the average removal rate of $\mathrm{COD}, \mathrm{NH}_{3}-\mathrm{N}$ and $\mathrm{TP}$ was $60.8 \%$, $55.7 \%, 55.6 \%$. At no tidal state, the average removal rate of $\mathrm{COD}, \mathrm{NH}_{3}-\mathrm{N}$ and $\mathrm{TP}$ was $57.5 \%$, $47.5 \%, 8.6 \%$. At the tidal state, the upper bio-film was exposed to air and the activity of microorganism decreased, and the activity of microorganism was high at middle-level bio-film. Therefore, the utilization of bio-film at the tidal state was lower than that at no tidal state. However, due to the tidal action, rivers entered into the dosing pool and the dilute effect of rivers on the pollutants was obvious.

\section{Acknowledgement}

The financial support of National Social Science Fund Major Tender Project (14ZDA071) was gratefully acknowledged.

\section{References}

[1] J.J. Cairns: Environ. Profess. Vol. 13 (1991), p. 1186

[2] B.E. Rittmann and P.L. Mccarty: MeGraw-Hill Com Inc. Vol. 5 (2001), p. 695

[3] B.N. Aronstein and M. Alexander: Appl. Microbiol Biotechnol. Vol. 39 (1998), p. 386

[4] A. Field, F.J. Gervantes and F.P. Vander Zee: Water Sci. Technol. Vol. 42 (2000), p. 215

[5] D.R. Lovley, J.C. Woodward and F.H. Chapelle: Appl. Environ. Microbiol. Vol. 62 (1996), p. 288

[6] M.A. Aly: Water Res. Vol. 32(1998), p. 944

[7] Y. Hyungseok: Water Res. Vol. 33 (1999), p. 145

[8] S.H. Lee and J. Kim: Bioresource Technol. Vol. 99 (2007), p. 2578 